\title{
GPC3 Gene
}

National Cancer Institute

\section{Source}

National Cancer Institute. GPC3 Gene. NCI Thesaurus. Code C88173.

This gene is involved in heparin sulfate binding. 